\title{
Comparative Study of Chinese and Western Cultural Differences in British and American Literature
}

\author{
Tang Tianqing \\ Sichuan Provincial Cadre Correspondence College; Chengdu 610213 China
}

Keywords: Cultural background; British and American literature; Differences; History; Taste

\begin{abstract}
Culture is the content that contains the history, tradition, custom, lifestyle, ideology of a country or nation. Different countries and nations in the world all have their unique cultural deposits. Culture is a social phenomenon and the result of human's long-term life experience. The differences between Chinese and western cultures are reflected in many aspects, one of the typical representatives of culture is literature. By analyzing the differences between Chinese and western cultures and the process of the formation and development of western culture, this paper explains how Chinese people should effectively read British and American literature to improve their appreciation and understanding of western culture, and explores the differences between Chinese and western cultures.
\end{abstract}

\section{Introduction}

For people living in different regions of the world, to understand the different cultures in their own regions, literary works are the best choice for people. For example, many of us Chinese have never been abroad before and have never had the opportunity to truly experience the cultural atmosphere in Britain and America. However, the Chinese people also know that many British and American cultures are particular about culture, such as catchphrases, table culture, polite expressions, etc. [1]. These are based on the knowledge accumulated by Chinese people from reading British and American literature. The cultural differences between China and the west are the inevitable trend of history. If we want to better understand British and American literature, we must understand the differences between Chinese and western cultures. When we read the British and American literary works, we should fully compare the differences between Chinese and western cultures, so as to understand the connotation of the works.

\section{What Is Culture}

Culture in a region is a set of the sum total of material wealth and spiritual wealth, it is a trial and error in the human history and creation, is a kind of oneself want to express a certain meaning at the same time also want to let others know that they have the idea, it is a long process of learning is advantageous to the ancient people's collective life, is a through thousands of years of accumulation and unremitting great wealth to the inheritance and preserved. Culture is not unchanging. It changes with time, space and even a hot event. Therefore, culture is very complicated.

\section{Reasons for the Differences between Chinese and Western Cultures}

\subsection{Different economic systems}

China is a large country with a large population. For the survival of China's population, it used to rely on planting land. The economic mode is a typical natural economy. Person's survival depends on not only food, is also inseparable from the water, so the source of Chinese civilization depends on where there is river, it also promoted the development of the agricultural civilization, this kind of honesty duty of civilization thought conservative destined to develop out of Oriental culture, pay attention to no pain, no gain. No pains, no gains, showing a laid-back attitude. And the ancient Greek civilization originated in the Aegean sea in the west, it is different in China "agriculture civilization", but has created its own unique Marine civilization, the civilization culture of westerners don't like the Oriental pay attention to farming, but like the sea adventure, very outgoing cultural ideas, combined with the implementation of 
the industrial revolution in the west, the west gradually show the independence, equality and freedom of ideas.

\subsection{Different geographical locations}

Chinese geographical mostly in the land, and is surrounded by mountains, so the Chinese almost no interest in the rest of the world to explore, in a closed space almost no contact with the outside world, people's thought also become relatively conservative, discuss eyes only on the region, usually by analyzing the history records and to regulate their own behavior, thus make the Chinese introverted character, conservative, not good at to accept new things. The west's geographical location is mostly near the sea, which fosters western risk-taking. The spirit of exploration, they kept exploring the mysteries of nature at sea and accumulated the experience of doing business at sea. Meanwhile, due to the lack of land environment in the west, they learned how to fight for land with weapons and expand their space at sea. Such geographical environment has created the character of westerners who are not afraid of difficulties and dangers, brave to explore and dare to take risks.

\subsection{Different cultural backgrounds}

During the five thousand years of Chinese history, numerous dynasties kept changing, but Chinese culture did not decline due to the change of dynasties, but gradually became mature with the passage of time. This is because even though the dynasty in succession, but its culture has been no change, this is said Han culture in the history of China, under the successive dynasties for more, although there is also a minority during mastered the regime, but the content of the Han culture contains very wide, along with the culture of the minorities also included, so this is Chinese culture can be an important factor in a direct line of succession. Therefore, it can be seen that the Chinese culture has a strong vitality and includes ability. With dynasty in the history of the west is not like in China has been in power by the Chinese and the western dynasty is often because of the invasion of foreign nationality, western culture tradition is impossible to complete the next, dynastic change inevitably leads to the introduction of the new culture, thus result in only a few old cultures to survive, so today is a blend of western culture.

\subsection{Differences in religious beliefs}

Everyone knows that the native religion of China is Taoism, but many people believe in Buddhism, which was caused by the great efforts of the rulers of the tang dynasty. However, most Chinese people do not believe in any religion nowadays. Many people do not understand the true meaning of religious belief, and some even combine religious belief with feudal superstition. When some foreigners come to China, they cannot help but feel that "China is a country without religious beliefs". However, there are relatively many religions in the west, such as Catholicism, Christianity and Islam, which are developed in the west. Most importantly, almost everyone in the west has his or her own religious belief, which results in a strong religious color in western culture and some value judgments of religion [7].

\section{The Expression of Cultural Differences between China and The West}

\subsection{Different cultural origins}

Chinese culture originated from the land of China, and the "Yangshao culture" and "Hemudu culture" formed by the river were the origin of early Chinese culture. In ancient China, the territory area was larger than it is now, so the terrain and climate involved are also relatively complex, which is conducive to the long-term agricultural cultivation in China. Western culture originates from the sea. Western countries are close to the sea and lack land resources. Therefore, western culture presents the characteristics of the sea.

\subsection{Different customs and cultures}

Different nations have different customs, for the cultural differences between China and the west; the differences in customs and culture occupy an important aspect. In front of food culture, for example, the Chinese mainly food, eat with chopsticks, eat to go to the guest house should finish everything in your bowl to master cooking delicious, and the western countries is given priority to with meat, eat with forks and knives, to dinner guest house need to finally leave a little food on the bowl to have full; In terms of 
language and culture, there are many ethnic groups in China and different dialects in the same ethnic group, which resul ts in the diversity of Chinese language content. For western languages, they are unified and belong to one language family, and their content is relatively single. In terms of children education, in China, most of the children are raised by their parents and live with their parents, while in western countries, children need to be independent from their families and live separately from their parents. In terms of costume culture, Chinese people like colorful clothes, while western clothes are relatively monotonous and so on.

\subsection{Different moral customs}

China thought great changes have taken place in the spring and autumn period and the warring states period, this period is the period of transition from slavery to feudal system in our country, the liberation of the people's thought had been unprecedented, was represented by criticizing the Guan Zhong various thoughts rushed to open, legalism and Confucianism in China under accept edification of people-oriented education thought, has created the Chinese etiquette, know own corruption, understand the moral conservative ideas [2].Chinese also advocates the unity, there is a strong holistic thought, and for the west emphasizes personal heroism, worship personal struggle, and will produce a strong sense of pride, this can make people's thoughts are relatively open to western countries, will be no less of people in western countries show their own advantages and strengths, easy to accept other people's praise and praise, but in China, cultured is modest and low key [3].This can be seen from an example: two women walking along the beach in skirts, a Chinese woman, an American woman, when the sea breeze is out of fashion, Chinese women unconsciously pull their skirts to avoid exposure, while American women open their arms and shout "good."

\subsection{Different ways of thinking}

Chinese and western ways of thinking can be explained by writing letters. When Americans write a letter, what they want to express is usually put at the beginning of the letter content, while when Chinese write a letter, they usually start with some polite words. This typical case illustrates the difference between Chinese and western ways of thinking. When Americans read Chinese letters, they may feel confused and do not know what the Chinese want to express. However, when Chinese read American letters, they will think that Americans are very impolite. From this example, it can be seen that the western way of thinking is rational and clear, while the Chinese way of thinking focuses on traditional etiquette.

\section{The Formation and Development of Western Culture}

The development of western culture has gone through four periods: ancient Greece, Rome, modern culture and modern culture, while the contents of western culture travel include many aspects, such as the democratic spirit, that is, everyone is equal before the law; Rule of law, that is, the supremacy of law; Free spirit, that is, pay attention to its own unique development; Chivalry; Humanity and so on. The formation content of these western cultures gradually increases with the time, and it is still developing now.

\section{The Influence of Western Culture on British and American Literature}

Why are British and American literature loved by people all over the world? For those who are familiar with British and American literature, it is known that there are a large number of fascinating myths in British and American literature. This phenomenon is just a proof of the great influence of western culture on British and American literary works. Many of the myths in ancient Greece and Rome in western culture are quoted by American and British literary works. Secondly, the deep influence of western culture on British and American literary works is the bible, which is the product of Christianity and contains contents of humanities, geography, history, morality and other aspects [5]. Rich in language and emotion, it enables people to have infinite imagination, so it is quoted by many British and American literary works. 


\section{The Status Quo of Reading British and American Literary Works in China}

With the continuous development of the era of growing internationalization, to the common language in our country and the usage of the word frequency increasing, the number of British and American literature reading is also rising, so some academic researchers in order to let more people can easily read and in-depth understanding of British and American literature, began to make detailed comparison to Chinese and western cultural differences, but for the general public, British and American literature reading first basic knowledge to the reader's own culture demand is higher, at the same time, because of Chinese and western culture different, expression, historical background and cultural construction and so on, This makes it difficult for Chinese readers to understand the connotation of British and American literary works.

\section{How to Effectively Master the Reading of Western Literary Works}

Although Chinese and western cultures differ in different aspects, for Chinese people to read western literary works, they have their own skills. In fact, no matter what country's literary works are, they will depend on the historical background of their own country. Therefore, in terms of reading western literary works, as long as you are familiar with the historical background of western development, you can easily understand the connotation of western literary works [4]. Second: readers need to jump out of their own culture with the traditional thinking. For example, when Chinese people see "pine", "bamboo", "prune tree", they will think of words like "integrity" and "tenacity". Another example is a Chinese word "red", which not only represents this kind of color, but also reminds people of warmth, passion and celebration. However, in the west these objects are real objects, which have no symbolic significance [6]. Third, read more western literary works, only read more, read more, some of the things used to clear, to improve the reading speed of readers to western literary works, more conducive to the in-depth understanding of western literature contains the connotation; Fourthly, language is the carrier of literary works, while the creation of western literary works depends on English. Therefore, to master the effective reading method of western literary works, it is necessary to learn English well. English also changes in meaning with different environments, so readers need to accumulate knowledge to achieve mastery.

\section{Conclusion}

From the British and American literature, we can see the differences between Chinese and western cultures. However, the reasons for this difference are varied. The British and American literary works have become more and more popular among Chinese people in recent years, and it has become a major way for Chinese people to deeply understand western culture. We can learn and understand the charm of western culture from British and American literary works, so as to effectively promote cultural exchanges between China and western countries.

\section{References}

[1] Yao Yaping. Two basic trends of the change of modern Chinese appellation system. Application of language and literature. Journal of Wuhan University.2005.3

[2] Gallhuber, a review of concepts and definitions (Cambridge, 1952) lists 16 definitions. A study of modern Chinese and western comparative literature (I), pp. 456-463. Sichuan people's publishing house -1988 .

[3] Lu Lingping. Differences between Chinese and western cultural face views and their influence on communication mode [J]. Journal of Wuhan University of Technology. 2014, (3).

[4] Xie Hanxing. Translation strategies of public signs under the guidance of communicative translation theory [J]. Journal of Henan University of Finance and Taxation. 2014 (4). 
[5] Shao Tong. Expression of cultural differences between Chinese and western societies in cross-cultural communication [J]. Journal of Shenyang University of technology (social sciences edition).2011. (01):92-95.

[6] Chen Cuilan. Interpretation of English and American literary works under the differences between Chinese and western cultures [J]. Chinese Construction.2014. 02-73.

[7] Gao Xiaohui. The influence of cultural differences on the translation of British and American literature [J]. Journal of Education College, Heilongjiang Province. 2016. 06: 115-117. 